\title{
BAHASA ARAB DAN PERADABAN ISLAM: TELAAH ATAS SEJARAH PERKEMBANGAN BAHASA ARAB DALAM LINTAS SEJARAH PERADABAN ISLAM
}

\author{
Buhori \& Besse Wahidah
}

\begin{abstract}
Abstrak
Tulisan ini berusaha untuk mengungkap peran besar dari bahasa Arab terhadap kemajuan peradaban Islam. Bahasa Arab yang disebut-sebut sebagai bahasa yang memperoleh garansi dan "proteksi ilahi" menjadi bagian yang tidak dapat dipisahkan dalam sejarah perkembangan dunia Islam. Dari sekian banyak bahasa yang ada di dunia, bahasa Arab dianggap sebagai bahasa yang paling banyak menyandang atribut. la sering dinamai sebagai bahasa agama dan umat Islam, bahasa dhad (lughah ad-dhâd) dan bahasa warisan sosial dan budaya (lughah at-turâts). Bahasa Arab merupakan anak dari bahasa Semit, yang notabenenya merupakan kaum yang besar peranannya dalam sejarah peradaban kuno. Oleh karnanya, bahasa ini memiliki beberapa bahasa serumpun, seperti bahasa Ibrani yang dipakai dalam kitab Injil dan Taurat, dan bahasa Suryani.

Dalam sejarah peradaban Islam, bahasa Arab menjadi salah satu kunci keberhasilannya, yang salah satunya ditandai dengan adanya gerakan penerjemahan besar-besaran berbagai karya filosof Yunani dan ilmuwan Persia dan India ke dalam bahasa Arab, yang kemudian menjadi titik awal kemajuan peradaban dan khazanah keilmuan umat Islam.
\end{abstract}

Kata Kunci: Bahasa Arab, Bahasa Agama, Peradaban Islam

\section{A. Pendahuluan}

Bahasa merupakan wujud totalitas antar sub-sistem. Karenanya, objek yang dikaji dalam setiap studi bahasa adalah upaya identifikasi, analisis, korelasi lintas sub-sistem tersebut, yang tujuan pokoknya adalah terciptanya kebermaknaan bahasa sebagai media komunikasi manusia, baik antar individu, masyarakat, dan atau antar budaya. Bahasa sebagai bagian dari budaya akan selalu menyertai kehidupan manusia, dimanapun dan kapanpun mereka berada. Dengan demikian, bahasa merupakan konvensi simbol pada aktifitas sosial. Selain itu, bahasa juga memiliki peran yang sangat besar dalam perkembangan peradaban kehidupan manusia.

Salah satu bahasa besar di dunia ini yang banyak dipergunakan oleh umat manusia adalah bahasa Arab. Bahasa Arab dianggap sebagai bahasa yang paling banyak menyandang atribut. Selain disebut sebagai bahasa kitab suci Al-Qur`an dan hadis, bahasa Arab juga sering dinamai sebagai bahasa agama dan umat Islam, 
bahasa dhad (lughah ad-dhâd) dan bahasa warisan sosial dan budaya (lughah atturâts). Di samping itu, bahasa Arab tercatat sebagai bahasa nasional lebih dari 25 negara di dunia yang terletak di kawasan Timur Tengah, dan sebagian Afrika, serta menjadi salah satu bahasa resmi di Perserikatan Bangsa-Bangsa (PBB).

Jabir Qumaihah dalam Muhbib Abdul Wahab ${ }^{1}$ menegaskan bahwa bahasa Arab merupakan bahasa yang memperoleh garansi dan "proteksi ilahi" (al-himâyah alilâhiyah), seiring digunakannya bahasa Arab sebagai wadah ekspresi al-Qur'an (wi ầ al-Qur'an). Sebagai bahasa agama bagi umat Islam, bahasa Arab tidak dapat dilepaskan dari sejarah besar perkembangan peradaban Islam. Maju dan berkembangnya peradaban Islam sangat dipengaruhi oleh bahasa Arab. Bahkan peradaban Barat-pun mampu berkembang pesat karena memperhatikan bahasa Arab. Pengaruh bahasa Arab terhadap peradaban Eropa tersebut dapat dilihat dari syair-syair yang ditulis oleh bangsa Eropa. Menurut Abaniz, penulis asal Spanyol, bahwa sesungguhnya sebelum orang Arab datang ke Andalusia dan menyebarnya para pejuang dan pahlawan Muslim ke belahan Selatan, bangsa Eropa tidak mengenal syair-syair tentang kepahlawanan dan tidak juga memperhatikan etika, serta semangat perjuangan ${ }^{2}$. Pengaruh bahasa Arab dalam

1 Muhbib Abdul Wahab, Peran Bahasa Arab dalam Pengembangan IImu dan Peradaban Islam, Jurnal Arabiyat, 2014 perkembangan peradaban Islam tidak hanya terbatas di bidang seni saja. Banyak hal dari aspek kehidupan yang telah dipengaruhi oleh bahasa Arab, termasuk peradaban Romawi dalam banyak bidang, bahkan musik dan syair sekalipun.

\section{B. Sejarah dan Perkembangan Bahasa Arab}

Sebagian para Ahli berpendapat bahwa teori yang diangap paling baik untuk mengklasifikasikan dan menggolongkan bahasa yang ada di dunia harus berdasarkan pada hubungan kekerabatan, maka berdasarkan teori ini bahasa-bahasa di dunia dikelompokkan menjadi dua rumpun, yaitu rumpun bahasa Indo-Eropa dan bahasa Semit-Hamit ditambahkan lagi oleh Max Muller dan Brunesen satu Rumpun bahasa ketiga yang di istilahkan dengan rumpun Turania. ${ }^{3}$

Salah satu ras manusia yang besar peranannya dalam sejarah peradaban kuno adalah bangsa Semit, dimana bangsa semit sendiri terbagi menjadi Semit-Utara dan Semit-Selatan, Jazirah Arab yang merupakan tanah kelahiran Islam merupakan Tanah air dari bangsa Semit, disamping itu juga karena beberapa Nabi pembawa Risalah juga berasal dari para keturunan bangsa Semit seperti Nabi Musa pembawa Risalah Yahudi, Isa pembawa Risalah Nasrani, dan Nabi Muhammad Saw

2 Musthafa as-Siba'i, Min Rawa'i' Hadharatina, (Beirut: Darul Irsyad), hIm. 42

3 Mudjia, Kholil R, Sosiolinguistik Qur'ani (Malang: UIN Malang Press, 2008), hlm. 38. 
sebagai pembawa risalah Islam. Dalam kurun waktu yang begitu panjang akhirnya keturunan mereka pun berpindah ke berbagai wilayah subur yang dikenal sebagai bangsa Babylonia, Assyiria, Phonesia dan bangsa Yahudi, begitu pula bahasa-bahasa yang mereka pakai juga dapat digolongkan menjadi beberapa bagian diantaranya :

1. Setengah kawasan Bagian utara ;

Timur : Akkad atau Babylonia; Assyria

Utara : Aram dengan Ragam timurnya dari bahasa Syria dan bahasa Aram inilah yang dituturkan oleh penduduk tanah suci Nabi Isa, Mandaca, dan Nabatea serta ragam baratnya dari Samaritan, Aram yahudi dan Palmyra.

Barat : Feonisia, Ibrani Injil, dan dialek kan'an lainnya.

2. Setengah Kawasan bagian selatan:

Utara : Arab

Selatan : Sabca atau Himyari dengan ragam dan dialek Minaea, Mahri, dan Haikili; dan Geez atau Etiopik, dengan ragamnya dari dialek Tigre, Amharik, dan Harari.

4 Wildana Wargadinata dkk, Sastra Arab Dan Lintas Budaya, (Malang: UIN Malang Press 2008), hlm. 27

5 Al-Hakim an-Naishaburi, al-Mustadrak 'alaAsshohihaini, Juz 2, (Maktabah Syamilah: Isdhar Tsani), hlm. 476.
Hampir seluruh bahasa itu kini sudah punah, kecuali bahasa Arab yang sampai saat ini masih hidup dan terus digunakan. ${ }^{4}$ Sedangkan untuk menetukan siapa yang pertama kali berbicara bahasa Arab masih banyak sekali perdebatan tentangnya, sebagian dari mereka berpendapat yang pertama kali berbahasa Arab adalah Nabi Isma'il sebagaimana dalam sabda Nabi Muhammad Saw yang diriwayatkan oleh Hakim dan Baihaki dari Jabir.

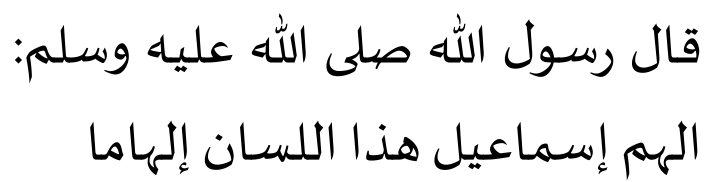

"Nabi Ismail benar-benar diberi ilham dengan lisan ini (bahasa Arab)"

Hadis di atas juga dipertegas dengan adanya hadis lain yang secara sorih menyebut bahwa orang yang pertama kali berbicara dengan bahasa Arab yang nyata adalah Ismail bin Ibrahim AS.

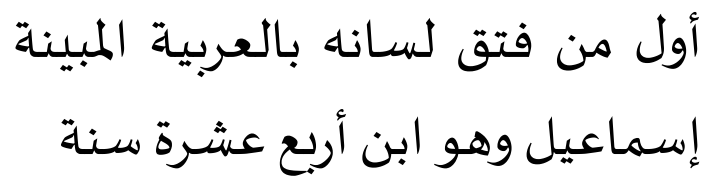

Orang yang pertama kali memperbaiki lisannya (bahasanya) dengan bahasa Arab yang nyata adalah Isma il pada saat beliau berusia empat belas tahun 6.

6 Jalaluddin as-Shuyuthi, Jami 'ul Alahdits, Juz 10, (Maktabah Syamilah: Isdhar Tsani), hlm. 303 
Sejarah bahasa Arab tidak bisa terlepas dari konteks Arab pra Islam (Arab Jahili) dimana kata "Arab" dalam masa praIslam berarti bangsa yang hidup di daerah semenanjung Arab. Semenanjung Arab terbagi menjadi dua bagian, yang pertama : kelompok masyarakat kota seperti Mekkah,Yasrib atau Madinah, serta di kotakota besar Yaman serta negeri Hirah di sebelah selatan Irak dan sebagainya, sedangkan bagian yang kedua : kelompok masyarakat Badui yaitu kelompok masyarakat yang tidak menetap dan selalu berpindah-pindah tempat, dimana diantara dua kelompok tersebut belum terjalin satu hubungan erat atau satu kesatuan antara keduanya, sehingga satu sama lain masih saling mempertahankan tradisi serta sistem hidup dan kebiasaannya sendiri, yang termasuk didalamnya pula dalam bidang bahasa, hal inilah yang memunculkan banyaknya dialek Arab waktu itu.

Dalam perkembangannya, ketika Mekkah menjadi pusat aktivitas serta tempat perkumpulan para anggota kabilah, disitulah mereka mulai merasakan adanya satu kebutuhan untuk bisa saling mengerti, termasuk dalam dialek dan bahasa yang mereka gunakan, sehingga diadakanlah alAswaq yang menjadi pusat perdagangan sekaligus kebudayaan, yang didalamnya diselenggarakan berbagai perlombaan serta diskusi tentang karya sastra baik syair maupun pidato ${ }^{7}$. Dan ini juga didukung

\footnotetext{
${ }^{7}$ Mudjia Raharjo \& Kholil R, hlm. 40
}

kecintaan para Rumpun Semit yang disini adalah Jazirah Arab terhadap kesenian besar, dengan kata lain jika orang Yunani menuangkan watak seninya terutama dalam bentuk patung dan arsitektur maka orang Arab menuangkan bentuk Seninya dalam bentuk Syair, ${ }^{8}$ Dalam perlombaan yang disebut al-Aswaq itu setiap peserta dituntut untuk terus berupaya memikat para hadirin dengan tujuan bahasa yang mereka pakai bisa dipahami dan dimengerti oleh semua yang hadir dalam acara itu, Dalam setiap perlombaan ternyata dialek orangorang Quraisy lah yang selalu mampu mendominasi dan dianggap lebih baik dari dialek-dialek lainnya.

Berangkat dari dialek Quraisy ini akhirnya terbentuk suatu bahasa kesusastraan yang menjadi bahsa baku (standar) yang selalu digunakan para penyair, pidato serta para cendekiawan dan bahasa itu adalah bahasa Arab Quraisy, sehingga dapat disimpulkan kalau bahasa Arab standar berasal dari dialek kabilah Quraisy yang kemudian dikembangkan dan disempurnakan dengan unsur-unsur dari dialek lainnya. Oleh karenanya bahasa Arab standar pada masa pra-Islam termasuk bahasa sastra yang sangat dibanggakan oleh semua orang meskipun untuk percakapan di lingkungannya masing-

${ }^{8}$ Philip K. Hitti, History of the Arab, (Jakarta: PT Serambi Ilmu Semesta, 2008), hlm. 112 
masing mereka masih menggunakan dialek mereka sendiri. ${ }^{9}$

Menjelang munculnya Islam lahirlah bahasa Arab standar yang menjadi bahasa Lingua Franca (al-Lughah al-Musytarikah), cepatnya perkembangan bahasa Arab standar ini di sebabkan oleh kebanggan masyarakat terhadap bahasa tersebut, sehingga seakan-akan penguasaan bahasa itu akan menjadi syarat bagi yang ingin diakui menjadi orang terkemuka dalam masyarakat, sedangkan ciri bahasa Arab standar ini adalah derajatnya sangat tinggi dibanding dengan dialek-dialek atau percakapan mereka sehari-hari karena bahasa Arab standar ini jauh dari ciri-ciri yang bersifat kedaerahan atau yang ada kaitannya dengan daerah tertentu.

Bahasa Arab bukanlah bahasa yang statis, karena bahasa ini terus mengalami perkembangan seiring dengan berkembangan ilmu-Sains dan Teknologi, dan ini di pengaruhi beberapa faktor diantaranya: faktor sejarah, penduduk, geografi, politik dll.

Berdasarkan perkembangan dan kondisi politik serta sosial-budaya yang mengelilinginya bahasa Arab mengalami perkembangan yang begitu pesat, dimana perkembangan itu terbagi menjadi lima fase;

1. Bahasa Arab standar sesudah kedatangan Islam

Agama Islam datang menjadi agama Rahmatan lil 'Alamin serta diturunkannya al-
Qur'an yang berbahasa Arab standar menjadikan bahsa Arab menjadi sesuatu yang sangat penting dan menarik perhatian masyarakat. Pada masa ini bahasa Arab masih dipandang bahasa yang terhormat dan berwibawa, ini disebabkan karena belum adanya sosialisi antara orang-orang Arab yang menaklukkan sebuah wilayah dengan penduduk sekitar, dimana saat pemerintahan Umar mereka dilarang memiliki hak milik terhadap daerah yang baru mereka tempati melainkan mereka tetap harus tinggal di perkemahan.

2. Bahasa Arab pada masa bani Umayyah Pada masa ini sudah ada sosialisasi orang Arab dengan penduduk asli, kondisi itu dikarenakan adanya rasa saling membutuhkan diantara mereka, kondisi ini menuntut orang Arab (pendatang) untuk terus berkomunikasi dengan penduduk asli baik dalam hal memasak, berdagang dll. Meskipun demikian berbicara Bahasa Arab dengan fasih masih menunjukkan ketinggian kelas sosial dan kelas tersendiri di masyarakat, diantara faktor yang menjadikan bahasa Arab pada posisi itu adalah pengaruh pasca adanya Arabisasi yang berjalan lancar melalui penyebaran Islam. Serta administrasi pemerintahan mulai tertata rapi dan profesional sejak kirakira tahun $87 \mathrm{H}$, hingga akhirnya bahasa Arab menjadi bahasa resmi negara Islam. Bahasa Arab selain menjadi bahasa al-

\footnotetext{
9 Mudjia, Sosiolinguistik..., hlm. 41.
} 
Qur'an juga menjadi bahasa yang digunakan untuk sebagian besar praktek ibadah, sehingga setiap muslim terus dituntut untuk mempelajarinya demi memenuhi kebutuhannya. ${ }^{10}$

\section{Bahasa Arab pada masa bani 'Abbasiyah \\ Pada masa ini peranan dan fungsi} bahasa Arab tidak serta merta terjatuh seiring dengan jatuh dan runtuhnya bani 'Abbasiyah, namun pada masa ini bahasa 'Ammiyah atau Arab al-Muwalladah mulai digunakan oleh kalangan terpelajar serta digunakan sebagai alat komunikasi, sehingga bahasa Arab Badui dipandang menjadi bahasa yang bermutu tinggi, sehingga tidak asing jika suatu waktu orang Badui dipanggil ke istana untuk menjadi guru Bahasa Arab. Pada masa ini juga menjadi masa kecermelangan penerbitan buku-buku berbahasa Arab, sehingga belajar bahasa Arab melalui orang Badui tidak dianggap lagi menjadi hal yang ideal untuk proses pembelajaran.

\section{Perkembangan bahasa Arab pada abad ke 5-H \\ Periode ini dimulai sejak pasca} terpecahnya dunia Arab seiring dengan masuknya paham sekularisme pada sebagian negara Islam serta pemerintahan islam telah dipimpin oleh Non-Arab, pada masa inilah bahasa Arab sudah tidak lagi

\footnotetext{
$10 \mathrm{lbid}, \mathrm{hlm} .42$.
}

menjadi bahasa politik serta administrasi pemerintahan, melainkan hanya menjadi bahasa agama saja, sehingga kesalahan dalam berbahasa Arab (lahn) pun menjadi hal yang biasa, seiring pula dengan berkurangnya minat masyarakat untuk mempelajari bahasa Arab.

\section{Bahasa Arab pada zaman baru}

Periode ini diklasifikasikan menjadi dua bagian; pertama yaitu: Classical Arabic, yaitu bahasa Arab al-Qur'an, alSunnah dan bahasa Arab zaman kuno sampai sebelum zaman modern dimulai sejak mesir diduduki Prancis, 1798 ), sedangkan yang kedua adalah: Neo Classical atau modern Arab yang secara resmi digunakan sebagai bahasa satra Arab modern, bahsa buku-buku ilmiah, Surat Kabar, pidato serta bahasa administrasi pemerintahan di Negara Arab, sedangkan untuk bahasa sehari-hari mereka menggunakan 'Ammiyah atau di sebut bahasa Arab baru. ${ }^{11}$

\section{Bahasa Arab dan Perkembangan Peradaban Islam}

Dalam catatan sejarah peradaban Islam, khususnya sejak masa Khalifah Malik ibn Marwân, Bahasa Arab tercatat menjadi bahasa resmi dan bahasa administrasi pemerintahan. Pada saat itu bahasa Arab diposisikan sebagai bahasa negara (dawlah Umayyah). Meskipun Arabisasi ini memang

11 Ibid, hlm. 45. 
agak bernuansa politis, karena Bani Umayyah tergolong memiliki "fanatisme yang kuat" (ta'ashshub qawiy) terhadap kesukuan dan kearabannya, dampaknya cukup luas dan signiikan. Namun secara perlahan, pengaruh bahasa Persia, Qibtia, dan bahasa Romawi sebagai bahasa administrasi di masa lalu (sebelum khilafah Umawiyah) kemudian digantikan oleh bahasa $\mathrm{Arab}^{12}$. Dengan demikian, pada masa itu, bahasa Arab tidak sekadar bahasa agama, melainkan juga sebagai bahasa negara: bahasa administrasi, birokrasi, diplomasi, dan bahasa transaksi sosial ekonomi.

Ketika dinasti Abbasiyah berkuasa, menggantikan dinasti Umayyah, orientasi dan tradisi keilmuan mendapat ruang dan momentumnya yang relevan dan signiikan. Bersamaan dengan itu, atas kebijakan khalifah Hâ rû n al-Rasyîd (786-809 M) dan terutama al-Ma'mû n (813-833 M), gerakan "intelektualisasi" berjalan mulus dan memperlihatkan kesuksesan yang luar biasa. Proses intelektualisasi dan sivilisasi (pemeradaban) umat Islam ini, tentu saja tidak dapat dipisahkan dari pergumulan dan interaksi sosial budaya dan pemikiran antara umat Islam dengan berbagai bangsa lain, utamanya bangsa-bangsa bekas dominasi Romawi (seperti Suriah, Turki, Palestina, Yordania) dan Persia yang memang meninggalkan khazanah keilmuan di berbagai bidang keilmuan. Yang menarik dalam konteks ini adalah bahwa sang khalifah yang menginstruksikan gerakan penerjemahan besar-besaran berbagai karya filosof Yunani dan ilmuwan Persia dan India ke dalam bahasa Arab. Di antara buku yang diarabkan saat itu adalah al-Tasyrîh (Pembedahan) karya Jalinus, al-Handasah (Arsitektur) karya Plato, al-Majesti karya Ptolemios, dan al-Samâ' wa al-'Âlam karya Aristoteles.

Pada saat Islam terus berkembang ke wilayah di luar Jazirah Arab, dengan sendirinya bahasa Arab ikut dikenal oleh masyarakat luas. Seperti halnya yang terjadi di Andalusia, bahasa Arab dikenal oleh penduduk Andalusia pertama kali seiring dengan masuknya Islam ke wilayah tersebut. Sejalan dengan pesatnya kejayaan Islam di Andalusia maka bahasa Arab pun mulai dipelajari oleh penduduk setempat. Dan pada akhirnya, bahasa Arab mampu menggantikan posisi bahasa lokal. Bahasa Arab mampu diterima oleh penduduk Andalusia dikarenakan bahasa Arab telah menjadi bahasa ilmu pengetahuan, budaya, dan pemikiran ${ }^{13}$. Untuk itu sangat wajar jika Islam mudah diterima oleh penduduk lain karena misi Islam adalah mengajarkan ilmu pengetahuan melalui perantara bahasa Arab.

Basari (Jakarta: Obor Indonesia, 1989), h. 37

13 Philip K.Hitti, ... hlm. 138 
Seiring dengan semakin diterimanya bahasa Arab, maka berbagai cabang ilmu pengetahuan pun semakin berkembang. Pada abad ke-9 dan ke-12 banyak karyakarya yang diterbitkan, mulai di bidang kedokteran, sejarah, agama, astronomi, geografi dan lain sebagainya. Mayoritas karya tersebut ditulis menggunakan bahasa Arab. Banyaknya pakar yang lahir di Andalusia tidak dapat terlepas dari suatu masa yang sangat penting sepanjang sejarah peradaban Islam yaitu era penerjemahan manuskrip. Peradaban Islam berkembang pesat dengan adanya gerakan penerjemahan. Era penerjemahan ini mengalami masa kegemilangan pada masa daulah Abbasiyah yang dipelopori oleh Khalifah al-Mansur. Yang mana beliau mempekerjakan orang-orang Persia yang baru masuk Islam untuk pergi ke daerah Bizantium mencari naskah-naskah Yunani dalam berbagai bidang ilmu terutama di bidang filsafat dan kedokteran. Sementara perburuan manuskrip ke daerah Timur seperti Persia lebih diutamakan mencari naskah tentang tata negara dan sastra. Tujuan pencarian naskah tersebut ialah untuk diterjemahkan ke dalam bahasa Arab dengan melakukan proses penyesuaian terhadap nilai-nilai Islam. Dari masa penerjemahan tersebut telah didapatkan karya-karya besar. Misalnya, Nawbaht, Ibrahim al-Fazari, dan Ali Ibn Isa yang telah

${ }^{14}$ Ada kurang lebih 14 bacaan dalam al-Qur'an yang menggunakan kalimat 'Arabiy, diantaranya al-Ra'd ; 37, Ibrahim :4, an Nahl :103, Thaha : 113, as-Syura : 7 dll. menerjemahkan karya-karya berbahasa Persia dalam bidang astrologi (ilmu perbintangan). Kemudian ada juga buku tentang ketatanegaraan dan politik serta moral yang berhasil diterjemahkan dari bahasa Persia ke dalam bahasa Arab. Dan berbagai manuskrip-manuskrip berharga lainnya pun berhasil diterjemahkan ke dalam bahasa Arab.

\section{Bahasa Arab Sebagai Bahasa}

\section{Al-Qur`an dan Hadis}

Penting kiranya menurut penulis untuk membahas lebih dalam tentang sejarah bahasa Arab terkait dengan digunakannya bahasa ini menjadi bahasa kitab suci yang menjadi mukjizat Nabi Muhammad SAW dan seluruh ummat manusia, disamping karena kitab ini adalah kitab suci ummat islam yang berisi segala pedoman hidup manusia yang tidak akan pernah punah, kitab ini juga terjaga keontetikannya sampai pada akhir zaman.

Al-Qur'an bukan hanya sekali menyebut kata Arabiy, dalam artian bahwa kitab suci ini benar-benar menggunakan bahasa Arab, dalam surat al-Ra'd ${ }^{14}$ misalnya: ${ }^{15}$

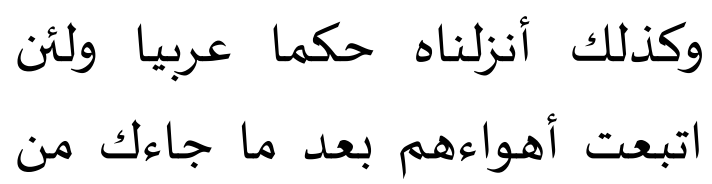

15 Mudjia Raharjo, Kholil R, Sosiolinguistik Qur'ani (Malang : UIN Malang Press, 2008), hlm. 35. 
العلم ما لك من الله من ولي ولا واق

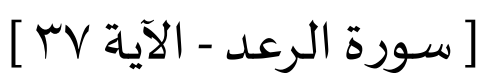

"Dan Demikianlah, kami Telah menurunkan Al Quran itu sebagai peraturan (yang benar) dalam bahasa Arab, dan seandainya kamu mengikuti hawa nafsu mereka setelah datang pengetahuan kepadamu, Maka sekalikali tidak ada pelindung dan pemelihara bagimu terhadap (siksa) Allah."

Dalam banyak kitab Tafsir, lafadz 'Arabi disini ditafsiri dengan bahasa Arab dengan maksud untuk mempermudah pemahaman dan hafalan untuk orang Arab itu sendiri. ${ }^{16}$

Diturunkannya al-Qur'an dengan bahasa Arab bukan berarti al-Qur'an bersifat lokal hanya untuk orang Arab saja, dan bukan berarti Allah tidak tahu kalau di bumi akan ada ribuan bahasa yang di pakai oleh seluruh ummat di dunia ini, namun Allah telah menetapkan satu bahasa yaitu bahasa Arab sebagai bahasa kitab suci ummat Islam, sehingga wajar kiranya kalau bahasa Arab pada akhirnya menjadi obyek menarik sebagai penelitian dari berbagai aspek dan dari sisi mana kita melihatnya, baik dari segi huruf, kata, tata bahasa dan lain-lain. Berangkat dari pemahaman ini pulalah orang-orang Orientalis terus merongrong Islam dari dalam dengan cara menyebarkan anggapan-anggapan keliru tentang bahasa al-Qur'an yang menurut mereka menggunakan bahasa Arab Quraisy, dengan artian al-Qur'an juga telah terkontaminasi oleh budaya Arab, dan kalau benar adanya mengapa tantangan Allah untuk membuat hal yang serupa dengan alQur'an tidak pernah terjawab, sebagaimana dalam surat al-Isra:

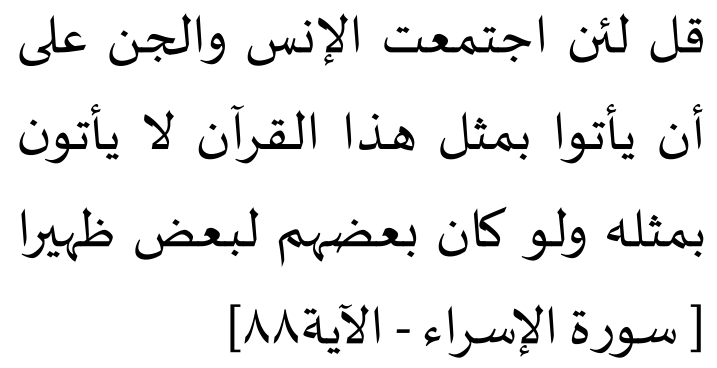

"Katakanlah: "Sesungguhnya jika manusia dan jin berkumpul untuk membuat yang serupa Al Quran ini, niscaya mereka tidak akan dapat membuat yang serupa dengan Dia, sekalipun sebagian mereka menjadi pembantu bagi sebagian yang lain".

Tantangan inilah yang tidak pernah mampu mereka jawab padahal para penyair dan pakar bahasa Arab saat diturunkannya al-Qur'an berhamburan dan tidak terhitung jumlahnya, atau dengan kata lain kalau benar adanya al-Qur'an telah terpengaruh oleh budaya Arab bahkan menjunjung tinggi superioritas suku Quraisy karena al-Qur'an turun dengan bahasa mereka tapi kenapa justru orang-orang kafir Quraisy sendiri saling melarang satu sama lain untuk mendengarkan al-Qur'an. ${ }^{17}$
${ }^{16}$ Wahbah Zuhaili, al-Tafsir al-Munir (Kairo : Dar al-Fikr, 2003 ), vol. 7. hlm. 195
17 Henri Shalahuddin, al-Qur'an Dihujat, ( Jakarta : Al-Qalam, 2007 ), hlm. 110-111. 


\section{E. Perbandingan bahasa Al-Qur'an dengan Taurat dan Injil}

Pada dasarnya al-Qur'an adalah pembenaran tentang keberadaan kitabkitab sebelumnya, sehingga tidak ada sebuah perbedaan yang mencolok antara beberapa kitab-kitab suci tersebut dalam hal sumber dan kontekstual dari kitab-kitab suci itu kecuali hanya keberadaan kitab suci alQur'an yang diturunkan dengan bahasa Arab yang jelas sesuai dengan firman Allah,

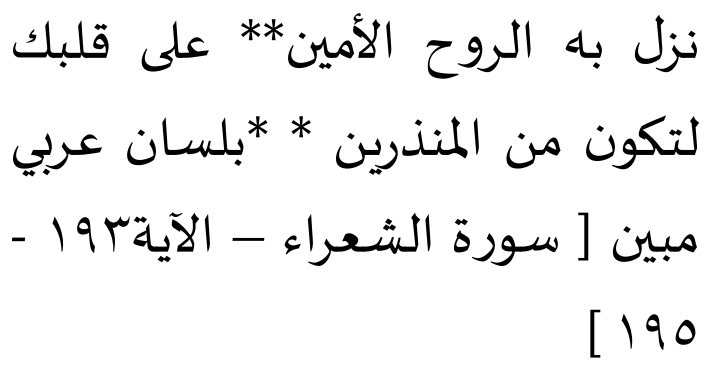

"Dia dibawa turun oleh Ar-Ruh AlAmin (Jibril), Ke dalam hatimu (Muhammad) agar kamu menjadi salah seorang di antara orang-orang yang memberi peringatan,Dengan bahasa Arab yang jelas."

Namun yang perlu dicermati turunnya al-Qur'an dengan bahasa Arab bukan berarti akan menonjolkan satu bahasa tertentu dibandingkan dengan bahasa yang lain, hanya saja efektifitas dakwah dengan didukung bahasa yang komunikatif akan lebih efisien hasilnya, sebagaimana firman Allah:

$$
\begin{aligned}
& \text { ولو جعلناه قرآنا أعجميا لقالوا لولا } \\
& \text { فصلت آياته أأعجمي وعربي قل هو } \\
& \text { للذين آمنوا هدى وشفاء والذين لا } \\
& \text { يؤمنون في آذانهم وقر وهو عليهم عمى }
\end{aligned}
$$

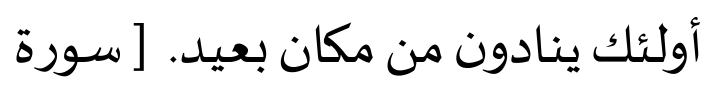

$$
\text { فصلت - الآية ع ع الية }
$$

"Dan Jikalau kami jadikan Al Quran itu suatu bacaan dalam bahasa selain Arab, tentulah mereka mengatakan: "Mengapa tidak dijelaskan ayatayatnya?" apakah (patut Al Quran) dalam bahasa asing sedang (rasul adalah orang) Arab? Katakanlah: "Al Quran itu adalah petunjuk dan penawar bagi orang-orang mukmin. dan orang-orang yang tidak beriman pada telinga mereka ada sumbatan, sedang Al Quran itu suatu kegelapan bagi mereka"

Sedangkan makna lisan Arabiyy itu haruslah dimaknai dengan pemaknaan yang lebih kompleks, makna Arabiy tidak hanya berkisar pada bahasanya namun lebih kepada peradaban yang ada pada waktu itu. Oleh karenanya, maka semua kitab-kitab suci sebelum al-Qur'an bersumber dari satu yaitu Allah, hanya saja ada beberapa perbedaan dari segi bahasa yang perlu di cermati, al-Qur'an dalam keberadaannya adalah sebuah percampuran dalam artian mempunyai dua sisi yaitu: Arabiyyatul lisan, namun kandungannya tetap kandungan ketuhanan, dan sulit kita temukan adanya perpaduan ini pada kitab-kitab suci yang lainnya, karena meskipun semua kitab suci itu turun sesuai dengan bahasa kaum tempat dimana kitab itu diturunkan, namun mereka hanya memuat ke Arabannnya saja dan tidak mengandung kearaaban yang mempunyai daya sastra yang begitu kuat, baik dari segi keindahan dan adanya keserasian antara 
satu ayat dengan yang lainnya seperti apa yang dimiliki oleh al-Qur'an, dimana dia memilki sifat l'jaz al-lughawi yang membuat para pakar ahli balaghah dimasanya pun tidak mampu untuk menandinginya.

Berbeda dengan keberadaan kitabkitab suci yang lain seperti Taurat dan Injil yang sama sekali tidak memiliki unsur l'jaz al-lughawi, sebab kalaupun ada mukjizat di dalamnya itu bukanlah bersumber dari isi dan keberadaan kitab itu sendiri, melainkan lebih kepada mukjizat yang timbul dari sang pembawa kitab suci, seperti tongkat yang dimiliki Nabi Musa ataupun kemampuan Nabi Isa untuk menyembuhkan orang buta dan bisu. ${ }^{18}$

Banyak kemungkinan adanya penyelewengan dalam kitab-kitab suci lain menjadi menarik untuk diteliti lebih lanjut tentang bahasa yang ada pada kitab-kitab suci selain al-Qur'an yaitu kitab Taurat dan Injil. Sejarah-sejarah agama Yahudi tidak mendukung adanya iman kepada teks Perjanjian Lama, ini disebabkan karena kebanyakan dari para penguasa adalah penyembah berhala, berbagai cara mereka lakukan untuk memalingkan diri dari Tuhan, Nabi Musa sendiri pun harus merasa puas dengan sebuah bangsa yang sama sekali tidak tahu berterima kasih kepada Tuhan dan kepadanya, bagaimana tidak, setelah

18 Muhammad 'Abid al-Jabiri, al-Madkhal ila alQur'an al-Karim, ( Beirut: Markaz Dirasat alWahdah al-'Arabiyah, .2007 ),hlm. 196

19 M.M. Al-A'zami, The History The Qur'anic Text From Revelation To Compilation, ( Jakarta : Gema Insani, 2005 ) terj.Sohirin Solihin Dkk, hlm. 259 diperlihatkannya beberapa mukjizat berupa pembelahan air laut, lalu dia meninggalkan kaumnya hanya dalam kurun waktu yang terhitung amat singkat yaitu 40 hari mereka sudah mendirikan patung anak sapi emas untuk disembah, ini memperkuat adanya keraguan tentang ketaatan Yahudi terhadap ajaran yang dibawa Nabi musa terlebih setelah masa hidupnya. Terlebih lagi Teks kitab-kitab suci mereka itu telah hilang lebih dari satu kali dimana tiap sekalinya berlangsung berabad-abad sedangkan para pembesar mereka hanyut dalam penyembahan berhala.

Bahasa yang digunakan Yahudi masa pra-pengasingan (pre-exilic Language) adalah dialek Kan'an dan tidak dikenal sebagai bahasa Ibrani, dan sebagian Ulama berpendapat memang pada kenyataannya tulisan-tulisan Yahudi pun berbahasa Kan'an, walaupun secara salah pada saat ini dianggap sebagai bahasa Ibrani lama atau Paleo Ibrani, ${ }^{19}$ sehingga pada intinya dalam perjanjian lama ada sebuah evolusi penulisan : Kan'an, Aram (Asyur) $^{20}$, dan setelah itu akhirnya Square, yang kemudian pada belakangan ini dianggap sebagai bahsa Ibrani, sehingga dapat disimpulkan bahwa dasar-dasar kesusastraan dan keagamaan yahudi itupun berasal dari masyarakat lain

20 karena pada awal masa Pra-Pengasingan tulisan yahudi berbahsa Kan'an namun setelah bahasa Aram menjadi bahasa dominan kawasan timur dekat kuno orang Yahudi juga mengadopsi bahasa ini dan segera mengambil tukisannya juga yang saat itu dikenal sebagai Asyur. 
yang menyebabkan adanya infiltrasi lebih jauh kedalam Perjanjian Lama mulai dari permulaan sejarah bangsa Israel yang paling awal misalnya:

1. Bahasa Ibrani diambil dari bahasa Funisia

2. Orang-Orang Yahudi tidak mengembangkan tulisan mereka sendiri, tapi sekedar menyesuaikannya dengan bahsa Aram dan Asyur.

3. Sistim diakritik Taurat Ibrani dipinjam dari bahasa Arab

4. Kitab perjanjian itu secara umumnya kemungkinan diadopsi dari Hammurabi, dst, dimana teks itu masih bersifat cair ( fluid ) sampai abad ke -10 M, hampir 2300 tahun setelah wafatnya Musa, dimana cair mempunyai arti teks itu masih terus terbuka untuk perubahanperubahan sesuai dengan justifikasi doktrinal yang cukup, dimana sekali teks itu mengalami perubahan yang perubahan itu menjadi sempurna maka yang asli akan dirusak sehingga menghapus semua jejak yang mengantarkan kembali pada sesuatu yang lebih tua. ${ }^{21}$

Pra-munculnya empat Injil seperti yang ada sekarang, para pengikut Yesus telah menyusun buku-buku mereka masingmasing, dimana disana tidak pernah ada hal yang dramatis seputar kehidupan Yesus serta riwayat-riwayat pengorbanan spiritual, fokusnya hanya terbatas pada ajaranajaranya saja, serta menjelaskan tentang pembaruan-pembaruan sosial yang ia canangkan, karangan inilah yang akhirnya dinamakan Injil $Q$, Injil $Q$ adalah lapisan yang sangat mencolok, dalam bahasanya penuh kata-kata simple tapi padat, tanpa adanya ajakan terhadap agama baru dan juga tidak pernah menjelaskan tentang Yesus Kristus adalah anak Tuhan, kondisi Injil pada abad pertama seperti inilah yang akhirnya memaksa orang-orang untuk menyisipkan lapisan-lapisan yang berbeda kepada $Q$, dimana lapisan yang kedua berisi tentang pergeseran nada yang menjanjikan sebuah kehancuran bagi mereka yang menolak pergerakan itu, dan yang lebih mencolok adalah yang terdapat pada lapisan ketiga dan terakhir yang disitu jelas disisipkan Yesus telah di up-Grade dari seorang Nabi yang bijak menjadi seorang anak tuhan (Son Of God), akan tetapi meski demikian tetap saja dalam lapisan ketiga ini tidak ada perintah untuk menyembah Kristus, Oleh karena itu $Q$ sebenarnya adalah Injil yang telah hilang dengan sangat cepat. dimana teks-teks yang kemudian menggantikanya berupa riwayat hidup kristus yang dramatis sehingga mengantarkan pada suatu pergeseran dalam fokus dan membantu menghidupkan mitos-mitos dan spekulasi yang sejak saat itu telah menutupi figur Yesus yang sebenarnya.

Mitos-Mitos Yesus ini terus beredar baik sebelum dan sesudah hilangnya $Q$, dan

\footnotetext{
${ }^{21}$ M,M The History The Qur'anic...,hlm. 293.
} 
dari sekian Injil yang terinspirasi dengan mito-mitos tersebut hanya empat yang mampu mencuat dan menonjol diantara yang lainnya: Injil Matius, Lukas, Markus dan Yohanes. ${ }^{22}$ Oleh karenanya Injil yang ada sekarang hanyalah merupakan tradisi dari lingkungannya serta bayangan mitosmitosnya tentang Yesus, disamping juga tidak satupun dari para pengarangpengaranya mampu mengklaim orang lain untuk menjadi saksi mata, namun sayangnya buku-buku yang disangsikan akurasinya pada masa-masa awal Gereja belakangan justru diberi otoritas besar melalui klaim bahwa buku-buku tersebut adalah karya-karya yang terinspirasikan Tuhan, dengan tujuan demi membenarkan tradisi-tradisi oral Kristen. ${ }^{23}$

Dari sini jelas bahwa keontetikan kitab suci ini justru sangatlah diragukan disamping dari sisi bahasa yang terus berkembang mengikuti periodeisasi juga mereka selalu menyisipkan beberapa teksteks yang dianggap sesuai untuk mendukung apa yang sedang diminati pengarangnya untuk mampu dijadikannya sebagai kekuatan yang mendukung segala keinginannya. Oleh karenanya sangatlah wajar kiranya ketika al-Qur'an dinobatkan sebagai mukjizat terbesar Nabi Muhammad serta ummat manusia di dunia, disamping karena keberadaannya yang selalu terjaga sejak awal di turunkannya sampai akhir zaman, pun karena al-Qur'an turun untuk sekaligus membenarkan apa yang telah diselewengkan dalam kitab-kitab suci sebelumnya sesuai firman Allah,

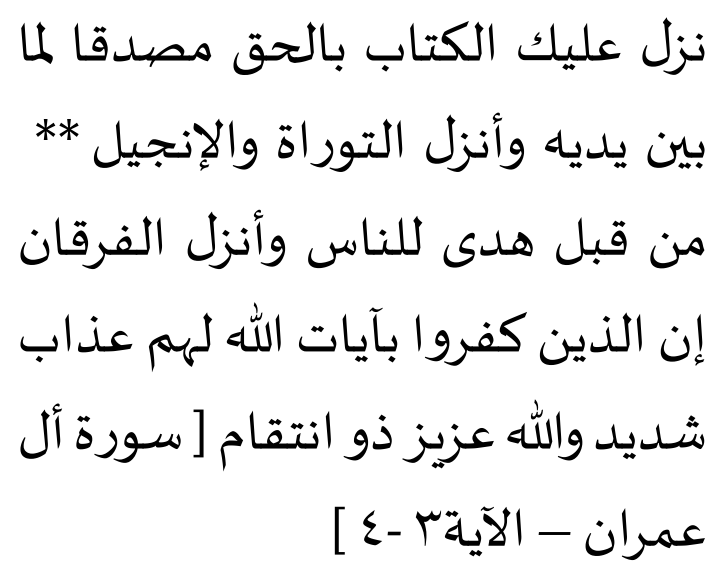

"Dia menurunkan Al Kitab (Al Quran) kepadamu dengan Sebenarnya; membenarkan Kitab yang Telah diturunkan sebelumnya dan menurunkan Taurat dan Injil,

Sebelum (Al Quran), menjadi petunjuk bagi manusia, dan Dia menurunkan al-Furqan (kitab yang membedakan antara yang benar da yang salah).sesungguhnya orang-orang yang kafir terhadap ayat-ayat Allah akan memperoleh siksa yang berat; dan Allah Maha Perkasa lagi mempunyai balasan (siksa)"

Makna Mushaddiq disini mengandung dua pengertian pertama ; alQur'an membenarkan adanya kitab- kitab yang turun kepada para Nabi sebelum Nabi Muhammad Saw, hanya saja perlu dicermati bahwasanya pembenaran ini terbatas kepada kita-kitab yang masih bersifat otentik dan bukan keberadaan 
kitab-kitab suci itu pada masa sekarang yang penuh dengan perubahan. kedua ; alQur'an datang untuk mengoreksi isi kandungan kitab-kitab Allah sbelumnya yang telah diselewengkan oleh para manusia yang tidak bertanggung jawab setelah Nabi penerima wahyu tersebut wafat. $^{24}$

Al-Qur'an adalah kitab sastra terbesar yang pernah dimiliki seluruh ummat yang kesusastraanya juga tidak ada tandingannya, apalagi jika dibandingkan dengan beberapa kitab suci sebelumnya. alQur'an adalah sebuah kitab dengan kefasihan yang sempurna, adanya keterkaitan antara satu dengan yang lain terjalin kuat, serta adanya keselarasan antara satu ayat dengan ayat yang lain terlihat sangat jelas, sehingga betul-betul memperindah kesusastraan yang dimilikinya. Disamping itu pula karena lafadz-lafadz al-Qur'an yang selalu sarat akan makna yang terkandung didalamnya.

Ada beberapa fakta yang membuktikan tentang indahnya kesusastraan yang dimiliki kitab suci alQur'an dibandingkan dengan kitab-kitab suci yang lain:

1. Meskipun al-Qur'an diturunkan atau diwahyukan dalam kurun waktu 23 tahun untuk kebutuhan dan tujuan yang berbeda-beda, ia memiliki satu

24 Ibnu Ahmad 'Alimi, Menyingkap Rahasia Mukjizat al-Qur'an, (Sidoarjo, : Mashun Press t.t ), hlm.17 keselarasan yang sempurna sehingga seolah-olah diwahyukan sekaligus.

2. Meskipun al-Qur'an diturunkan dalam kurun waktu 23 tahun di dalam peristiwa-peristiwa yang berbeda-beda, bagian-bagiannya saling mendukung satu sama lain sehingga seolah-olah alQur'an diturunkan sekaligus

3. Meskipun terkadang al-Qur'an turun untuk menjawab pertanyaan yang sama (berulang ) dan berbeda-beda namun tetap ada keselarasan diantara satu dengan yang lain sehingga seolaholah menjadi jawaban untuk satu pertanyaan saja

4. Meskipun al-Qur'an berbicara kepada berbagai jenis orang yang tak terhitung jumlahnya, yang terpisah jauh antara satu dengan yang lainnya dalam waktu, ruang dan karakter yang berbeda, ia mempunyai satu penjelasan, gaya bahasa, dan cara penggambaran yang sangat jelas sedemikian rupa sehingga seolah-olah ia ditujukan pada satu kelompok yang homogen (sama )

5. Meskipun al-Qur'an diwahyukan denga gaya bahasa yang bermacam-macam untuk menyesuaikan dengan tingkat pemahaman, suasana hati, dan tempramen yang berbeda dari banyak sekali orang, bagian-bagiannya menunjukkan kesamaan, persesuaian, 
dan kefasihan yang sangat indah sehingga seolah-oleh ia sedang menyapa satu tingkat pemahaman dan tempramen. ${ }^{25}$

\section{F. Penutup}

Berdasarkan uraian di atas dapat disimpulkan bahwa bahasa Arab, sebagai salah satu bahasa besar di dunia, merupakan bahasa yang memiliki peran besar dalam kemajuan peradaban Islam. Bahasa Arab tidak hanya "dinobatkan" sebagai bahasa agama, namun ia juga memiki berbagai macam atribut atau penamaan lainnya. Bahasa Arab yang tercatat sebagai bahasa nasional lebih dari 25 negara di dunia serta menjadi salah satu bahasa resmi di Perserikatan BangsaBangsa (PBB) ini, juga sering dinamai sebagai bahasa dhad (lughah ad-dhâd) dan bahasa warisan sosial dan budaya (Iughah at-turâts).

Dari aspek sejarah, bahasa Arab sendiri disebut sebagai bahasa turunan dari bangsa Semit, dimana bangsa semit sebadarj terbagi menjadi Semit-Utara dan SemitSelatan, Jazirah Arab yang merupakan tanah kelahiran Islam merupakan Tanah air dari bangsa Semit. Selain itu, manusia yang dianggap pertama kali menggunakan bahasa Arab adalah nabi Isma il putra Nabi Ibrahim `alaihimassalam, yang sekaligus menjadi nenek moyang bangsa Arab.
Keberadaan bahasa Arab sendiri tidak dapat dilepaskan dalam sejarah peradaban Islam. Proses intelektualisasi dan sivilisasi (pemeradaban) umat Islam ini, tidak dapat dipisahkan dari pergumulan dan interaksi sosial budaya dan pemikiran antara umat Islam dengan berbagai bangsa lain, utamanya bangsa-bangsa bekas dominasi Romawi. Dalam hal ini bahasa Arab menjadi salah satu kunci keberhasilannya, yang salah satunya ditandai dengan adanya gerakan penerjemahan besar-besaran berbagai karya filosof Yunani dan ilmuwan Persia dan India ke dalam bahasa Arab.

\section{G. Daftar Pustaka}

Al-Hakim an-Naishaburi, al-Mustadrak 'ala- Asshohihaini, Juz 2, (Maktabah Syamilah: Isdhar Tsani).

Bediuzzaman Said Nursi, Dari Balik Lembaran Suci, (Jakarta: Siraja, 2003).

Qadir, Filsafat dan IImu Pengetahuan dalam Islam, terj. dari Philosophy and Science in the Islamic World oleh Hasan Basari (Jakarta: Obor Indonesia, 1989).

Henri Shalahuddin, al-Qur'an Dihujat, (Jakarta: Al-Qalam, 2007).

Ibnu Ahmad 'Alimi, Menyingkap Rahasia Mukjizat al-Qur'an, (Sidoarjo: Mashun Press t.t). 
Jalaluddin as-Shuyuthi, Jami ul Alahdits, Juz 10, (Maktabah Syamilah: Isdhar Tsani).

M.M. Al-A'zami, the History the Qur'anic
Muhbib Abdul Wahab, Peran Bahasa Arab dalam Pengembangan IImu dan Peradaban Islam, Jurnal Arabiyat, 2014.

Text from Revelation Mutsthafa as-Siba'i, Min Rawa'i' Hadharatina, Compilation, (Jakarta: Gema (Beirut: Darul Irsyad).

Insani, 2005) terj.Sohirin Solihin Philip K. Hitti, History of the Arab, (Jakarta: Dkk.

PT Serambi Ilmu Semesta, 2008).

Mudjia Raharjo, Kholil R, and Wahbah Zuhaili, al-Tafsir al-Munir (Kairo: Sosiolinguistik Qur'ani (Malang: Dar al-Fikr, 2003), vol. 7. UIN Malang Press, 2008).

Wildana Wargadinata dkk, Sastra Arab Muhammad 'Abid al-Jabiri, al-Madkhal ila Dan Lintas Budaya, (Malang: UIN al-Qur'an al-Karim, (Beirut: Markaz Malang Press 2008).

Dirasat al-Wahdah

al-

'Arabiyah, .2007). 